Zusammenfassung. Unsere Erfahrungen bei 20 orthotopen Leber-Transplantationen bei Sehweinen und 55 Transplantationen bei Hunden haben ergeben, daß es viel leichter ist, eine lange Utberlebensdauer bei Schweinen zu erzielen. Diese Beobachtung beruht auf zwei Umständen: Erstens: die Schweine haben nur selten Rejektionen, zweitens: bei Hunden ist das wichtigste Hindernis die große Anzahl der thrombotischen Komplikationen.

\title{
77. Experimentelle Verpflanzungen heterologer Nerven
}

\author{
R. Metz*-Hamm, B. Braun und F. J. Lehnhardt-Melsungen
}

\section{Experimental Transplantation of Heterologous Nerves}

Summary. After a historical survey it is stated that clinical attempts of bridging defects of peripheral nerves by heterotransplantation have failed. An improvement of the success rate was anticipated from the further development of the lyophilisation method insofar as it provided a more complete desantigenisation of the nerves. After subcutaneous implantation of autologous, homologous and heterologous nerve segments comparative tests of the immunereaction were made. No significant difference was found in the reactions of the 3 groups. Subsequently heterotransplants $31 / 2 \mathrm{~cm}$ long were transplanted into resection gaps in the sciatic nerves of rabbits and dogs and covered with collagen tubes. There was satisfactory healing in all cases. EMG, sensation control and histological evaluation confirmed progressive regeneration beyond the site of transplantation in more than half the cases. The favourable results with a new material thus confirmed are encouraging. In view of the successful heterotransplantation of other tissues the production of nerve preserves is being attempted whose use causes no ethical or legal doubts.

Zusammenfassung. Nach einem historischen Rückblick wird festgestellt, daß die klinischen Versuche der Überbrückung von Defekten peripherer Nerven durch Heterotransplantationen scheiterten. Eine Besserung der Erfolgsquote versprach die Fortentwicklung des Gefriertrocknungsverfahrens im Sinne einer weitergehenden Desantigenisierung der Nerven.

Nach subcutanen Implantationen autologer, homologer und heterologer Nervensegmente wurde die Immunreaktion im Vergleich getestet. Es fand sich keine verwertbare Differenz der Reaktionen bei den 3 Gruppen. Anschließend wurden $31 / 2 \mathrm{~cm}$ lange Heterotransplantate in Resektionslücken der $\mathrm{n}$. ischiadici von Kaninchen und Hunden verpflanzt, Umhüllung mit Kollagentuben.

In allen Fällen kam es zur einwandfreien Einheilung. EMG, Sensibilitätskontrolle und histologische Auswertung bestätigten die fortschreitende Regeneration über die Transplantatstelle hinaus in mehr als der Hälfte der Fälle. Die dadurch belegten günstigen Ergebnisse mit einem neuartigen Material sind ermutigend. Im Hinblick auf die Erfolge der Heterotransplantation anderer Gewebe wird die Herstellung von Nervenkonserven angestrebt, bei deren Verwendung keine ethischen oder juristischen Bedenken bestehen. 